\title{
Learners' Challenges and English Educators' Approaches in Teaching Speaking Skills in an ESL Classroom: A Literature Review
}

\author{
Agatheswari Paneerselvam, Maslawati Mohamad \\ Faculty of Education, Universiti Kebangsaan Malaysia, Bangi, Malaysia \\ Email: aga_paru@hotmail.my
}

How to cite this paper: Paneerselvam, A., \& Mohamad, M. (2019). Learners' Challenges and English Educators' Approaches in Teaching Speaking Skills in an ESL Classroom: A Literature Review. Creative Education, 10, 3299-3305.

https://doi.org/10.4236/ce.2019.1013253

Received: October 7, 2019

Accepted: December 6, 2019

Published: December 9, 2019

Copyright $\odot 2019$ by author(s) and Scientific Research Publishing Inc. This work is licensed under the Creative Commons Attribution International License (CC BY 4.0).

http://creativecommons.org/licenses/by/4.0/

\begin{abstract}
Speaking skill is one of the most essential skills to be acquired as it is the means of communication around the globe. However, most of the English as second language learners (ESL), are still struggling to develop their speaking skills in English. Thus, this paper provides a literature review on the challenges faced by the ESL learners in learning speaking skills and English educators' approaches in teaching speaking skills. Some of the challenges faced by the ESL learners are lack of motivation and self-confidence, anxiety, inhibition and limited knowledge of vocabulary. Therefore, it is necessary to identify the approaches employed by English language educators in teaching speaking skills and enhancing the speaking skills among these learners from related past studies. Some of the English language educators' approaches in teaching speaking skills are by using social media such as Instagram, flipped classroom, debates and games as learning activities within and outside classroom. By identifying the approaches employed by other educators, ESL educators could select the ones which might be feasible in their own classroom.
\end{abstract}

\section{Keywords}

Speaking Skills, English as a Second Language (ESL), Elementary Pupils, Learners' Challenges, Educators' Teaching Approaches

\section{Introduction}

As the world is moving towards digitalization, English language is essential to be acquired by many people throughout the globe. Therefore, the upcoming future generations should be thoroughly equipped with English language to face the $21^{\text {st }}$ century world challenges. Speaking skill is one of the most essential skills to 
be acquired as it acts as the means of communication around the globe. Though listening, speaking, reading and writing skills share similar importance, however, speaking skill often dominates the other skills as speaking or in other words, communication is carried out in one's daily life in a frequent manner, both in formal and informal situations. According to Idrus \& Salleh (2007), oral communication is a major component of soft skills. In line with that, the researchers concluded that "good oral communication skills enhance soft skills" (Idrus \& Salleh, 2007: p. 62). Moreover, communication is one of the elements in 4C's of $21^{\text {st }}$ century skills, thus, the importance of the skill is very much clearer. Therefore, this is being the ultimate reason for the government of many countries to ensure the empowerment of speaking skill among the pupils is stated in the education policy in order to produce competent speakers of the English language. This is to enable them to be able to compete globally.

However, most of the English learners, specifically, English as Second Language (ESL) learners, are still struggling to develop their speaking skill. Based on past studies, this is due to some challenges faced by ESL learners in learning the target language to speak. Based on studies conducted by Savasci (2013) and Idrus and Salleh (2007) the reasons behind ESL students being reluctant to use the target language are high level of anxiety which is caused by the fear of being evaluated, educator's teaching method, and learners' culture.

The past studies that have been reviewed state that the major challenges that inhibit the ESL learners' speaking skills are lack of motivation and self-confidence, anxiety, inhibition and limited knowledge of vocabulary. Therefore, it is necessary to identify the possible ways in overcoming the ESL learners' challenges and enhancing the speaking skills among these learners. The past studies that have been reviewed have also suggested several approaches which have been proven as effective tools in overcoming the ESL learners' challenges and enhancing their speaking skills. The approaches and methods include using social media such as Instagram, flipped classroom, debates and games as learning activities within and outside classroom. Therefore, this paper provides a literature review on the challenges faced by ESL learners in learning speaking skills and English educators' approaches in teaching speaking skills. In line with this, this literature review study will attempt to provide answers to the following research questions:

- What are the challenges faced by the elementary school ESL learners in speaking skills?

- What are the effective elementary school English educators' approaches in teaching speaking skills in ESL classroom?

\section{Literature Review}

\subsection{An Overview on $21^{\text {st }}$ Century Demands on Speaking Skill}

$21^{\text {st }}$ century is merely known as the digital era where employability is highly competitive. Some of the $21^{\text {st }}$ century demands are highly professional or high techs workforce, the ongoing transformation of life towards a digital economy, 
individuals with problem-solving skills and high innovation skills with critical thinking ability. The main underlying component which connects these demands is communication as it plays a vital role in the $21^{\text {st }}$ century. "Communication is a requirement for any company to maintain profitability. It's crucial for students to learn how to effectively convey ideas among different personality types" (Systems, 2019). Moreover, Systems (2019) also added that learners without communication competence would fail to progress in terms of professional development.

Other than that, one's social skill has always been an advantage in the job market as a social skill connects one with another. In a research carried out by Casner-Lotto \& Barrington (2006) along with the Partnership of $21^{\text {st }}$ century (P21) on the readiness of workforce from the employers' perspective, they highlighted some skills that are considered by the employers in $21^{\text {st }}$ century are the ability to work collaboratively, to solve problems, think critically and communicate effectively. The ability to work collaboratively in a team is highly dependent on good communication skills in both oral and written. It is also important to note that several of the basic knowledge skills, such as reading comprehension, English Language (spoken), writing in English, and Mathematics are the skills that the employers highlighted as very essential to new employees.

Therefore, this gives a clear insight that education field plays a major role in molding and producing highly competitive citizens in terms of speaking skill, to the society, nation and the world. Furthermore, this is the underlying reason as to why the learner-centered approach has dominated the traditional teacher-centered approach in $21^{\text {st }}$ century learning. The educators are no longer function as the sole content delivery to the learners but act as facilitators who guide the learning process. The learners learn independently by exploring information and the educators behave as trainers who help the learners during their work or project. Moreover, the learners are trained and assessed through all the components of $21^{\text {st }}$ century learning which comprises communication, collaboration, critical thinking and creative thinking. Therefore, this clearly shows the importance of speaking skill in the $21^{\text {st }}$ century and it is certainly crucial to prepare the learners to be competent speakers by enhancing their speaking skill.

\subsection{Challenges Faced by ESL Learners in Learning Speaking Skills}

According to Krashen (1982), there are a number of affective elements that contributes to second language acquisition. However, the most encountered elements are motivation, self-confidence and anxiety. This was also supported by Oxford (1990) in which he states that one of the main contributors to the students' failure in their attitude. It is challenging for ESL learners in increasing their self-confidence, motivation and lowering their anxiety level. These elements are often interrelated whereby an increase in anxiety level will eventually decrease their self-confidence and motivation, thus, affects their performance. Therefore, high anxiety level is the main aspect which causes ESL learners from 
not using the targeted language, especially in a speaking classroom. This has been proven by various researchers through their respective articles such as Tuan and Mai (2015), Ansari (2015) and Savasci (2013).

Anxiety is the most ultimate challenge that frequently occurs in a speaking activity classroom and this adversely affects their educational goals (Ansari, 2015). Firstly, whenever the learners are corrected while they are speaking would certainly result in anxiety. The reasons behind this were explained by Tuan and Mai (2015). They state that if the students are corrected all the time when they made any mistake they could develop fear of making mistakes. The researchers also mentioned other contributing challenges faced by the learners which include time pressure and listening ability which eventually result in anxiety too.

Moreover, inhibition is also another challenge that is faced by ESL learners. Students always worried of making mistakes as they felt of being judged by others. As a result, they felt ashamed to express themselves in a foreign language. This deters them from trying to speak the target language (Tuan \& Mai, 2015: p. 10). This finding was also supported by Ansari (2015) in which his findings too revealed that the learners hesitated to participate in speaking activities because they were afraid of being teased by their friends. Therefore, inhibition causes the learners to be passive in the classroom.

The learners' limited knowledge of vocabulary is a concern of ESL learners too as they do not know how to express themselves. This concern was also supported by Tuan and Mai (2015) and Ansari (2015) in which they highlighted that low motivation caused the learners unable to express themselves as they could not construct sentences even though they have ideas on what to say in their first language. This scenario resulted in the learners to be passive too in the classroom as lack of vocabulary knowledge becomes a barrier for them to participate actively.

\subsection{Educator's Approaches in Teaching Speaking Skills in ESL Classroom}

The educators play an important role to overcome the challenges faced by the ESL learners in speaking English language. Therefore, it is the educator's responsibility to find the reasons behind the learners' low speaking ability thus, provide a friendly and fun filled learning environment that could engage the learners actively in the lesson (Leong \& Ahmadi, 2016). According to Lian and Budin (2014), educators should be able to produce a stress-free environment where learners do not fear of making mistakes, thus, lowering their inhibition.

These researches also suggested that the educators should be able to choose the best method which suits their learners in the classroom. In line with that, there are a number of approaches that educators may implement in enhancing the learner's speaking skill in the classroom. One of the approaches is by using social media such as Instagram. Handayani (2016) has discussed in her article stating that Instagram can be used as a tool in teaching English language. En- 
hancing speaking skill is also one of the advantages that could be retrieved from using this tool. Some speaking activities that are suggested by Handayani (2016) include capturing field trip memories, review a famous person in history, role play and pronunciation plus. These activities enable the learners to speak confidently thus lowering their anxiety as they feel motivated to talk about topics that are very close to them. This is also similar to the findings of Mansor and Rahim (2017) on Instagram in ESL.

Besides, flipped classroom is another approach to enhance ESL learners' speaking skill. Flipped classroom is where the learners are expected to do independent learners and further enhancement on the content is done in the classroom through activities such as discussion and debates. In a research conducted by Handayani (2016), the findings revealed that the ESL learners were more active in the classroom where they actively participated in the speaking activity unlike in a normal classroom. The research also suggested that this approach can also be used creatively using social media.

Apart from that, non-technology approaches would also help learners in enhancing their speaking skills such as debates. Othman (2014) has proved the effectiveness of having debate as a classroom activity to improve and develop learners' critical thinking skill along with speaking skills. The researchers also conclude that such activity would certainly help the learners to overcome their stage fright and build their self-confidence. In addition, as the learners participate in debate and listen to the others, they will also pick up new words thus, increase their vocabulary knowledge.

Games can also be used as an approach to guide and develop ESL learners' speaking skills. Games are always the learners' choice of having fun because it simply creates a fun filled environment. According to León and Cely (2010), games motivate learners to speak through a fun environment. The researchers further claimed that games made an increase in learners' participation in speaking. In conclusion, some of the suggested games in the literature review include sharing-caring, guessing and speculative game and a story game.

\section{Conclusion and Implications}

As mentioned earlier, this paper provides a literature review on the challenges faced by the ESL learners in learning speaking skills and English educators' approaches in teaching speaking skills. This is mainly due to the issue that is being circulated among ESL learners around the world where most of the English learners, specifically, the ESL learners, are still struggling to develop their speaking skills. Consequently, it is clear how important is the speaking skills, especially in the $21^{\text {st }}$ century.

It is necessary to identify the challenges faced by ESL learners in the learning process particularly in learning to speak effectively. Some of the challenges faced by the ESL learners are motivation, self-confidence, anxiety, inhibition and limited knowledge of vocabulary. Therefore, it is necessary to identify the ap- 
proaches employed by English language educators in teaching speaking skills and enhancing the speaking skills among these learners from related past studies. By identifying the approaches employed by other educators, English educators could select the ones which might be feasible in their own classroom.

Apart from that, the educators' teaching approaches are equally important to overcome these barriers of learners in speaking the target language. The past studies that have been reviewed and discussed earlier indicate that there are several suggested approaches which have been proven as effective tools in overcoming the ESL learners' challenges and enhancing their speaking skills. The approaches include using social media such as Instagram, flipped classroom, debates and games as learning activities within and outside classroom. Therefore, it is necessary for the educators to be aware of their learners' challenges and cater the learners' problems through interventions that address the learners' difficulties.

Some implications could be derived from this paper which could be useful for the ESL educators and learners. With regard to the learners' challenges faced in the classroom, the educators should be aware of the reasons behind it and choose the appropriate teaching approaches that are suitable to tackle the students' difficulties. Finally, ESL educators should also convey the importance of speaking skills to learners for them to have an insight into it. They should motivate the learners to at least try to use the target language.

\section{Conflicts of Interest}

The authors declare no conflicts of interest regarding the publication of this paper.

\section{References}

Ansari, M. S. (2015). Speaking Anxiety in ESL/EFL Classrooms: A Holistic Approach and Practical Study. International Journal of Educational Investigations, 2, 38-46.

Casner-Lotto, J., \& Barrington, L. (2006). Are They Really Ready to Work?: Employers' Perspectives on the Basic Knowledge and Applied Skills of New Entrants to the 21st Century U.S. Workforce. Washington DC: Partnership for 21st Century Skills.

Handayani, F. (2016). Instagram as a Teaching Tool? Really? In Proceedings of the Forth International Seminar on English Language and Teaching (pp. 320-327).

Idrus, H., \& Salleh, H. I. (2007). Perceived Self-Efficacy of Malaysian ESL Engineering and Technology Students on Their Speaking Ability and Its Pedagogical Implications. The English Teacher, 37, 61-75.

Krashen, S. D. (1982). Principles and Practice in Second Language Acquisition. Oxford: Pergamon Press.

León, W. U., \& Cely, E. V. (2010). Encouraging Teenagers to Improve Speaking Skills. PROFILE, 11-31.

Leong, L.-M., \& Ahmadi, S. M. (2016). An Analysis of Factors Influencing Learner's English Speaking Skill. International Journal Research in English Education, 2, 34-41.

Lian, L. H., \& Budin, M. B. (2014). Investigating the Relationship between English Language Anxiety and the Achievement of School Based Oral English Test among Malay- 
sian Form Four Students. International Journal of Learning, Teaching and Educational Research, 2, 67-79.

Mansor, N., \& Rahim, N. (2017). Instagram in ESL Classroom. Man in India, 97, 107-114.

Othman, M. (2014). Students' Perception toward Using Classroom Debate to Develop Critical Thinking and Oral Communication Ability. Asian Social Science, 11, 158-170. https://doi.org/10.5539/ass.v11n9p158

Savasci, M. (2013). Why Are Some Students Reluctant to Use L2 in EFL Speaking Classes? An Action Research in Tertiary Level. In 5th World Conference on Edcational Sciences (pp. 2682-2686). https://doi.org/10.1016/j.sbspro.2014.01.635

Systems, A. E. (2019).

https://www.aeseducation.com/career-readiness/what-are-21st-century-skills

Tuan, N. H., \& Mai, T. N. (2015). Factors Affecting Students' Speaking Performance at Le Thanh Hien High School. Asian Journal of Educational Research, 3, 8-23. 